\title{
Charms and Wands in John the Lazy: Performance and Beliefs in Argentinean Folk Narrative
}

\author{
María Palleiro \\ Full Professor, National University of Arts/Buenos Aires University, Argentina \\ Senior Researcher, Folk Narrative National Scientific and Technical Research Council, Argentina
}

\begin{abstract}
Virtue wands" do appear in Argentinean folk narrative as useful devices used by the hero to achieve his dreams. Using the correct charm and waving his wand, the Argentinean folk hero John the Lazy manages to marry the princess and to live without working. Charms show in this way how to do things with words, pronouncing the proper words in the right situation. In this presentation, I deal with the formulaic use of a magic charm in this Argentinean folktale, collected in fieldwork in 1988. This charm deals with an invocation to the "Wand of virtue" given to the hero by God's mercy, whose proper use shows the performative force of language. The tension between the absence of effort and the need of working is solved in this tale in a world of dream, in which the real effort is to learn how to use the correct words. Social beliefs in the supernatural are expressed in this tale, in which the wand is a God's gift that allows the hero to avoid struggling. But the main gift is actually the knowledge of language which permits the hero to make an accurate usage of formulaic discourse, structured in the charm in an epigrammatic way. In this way, I propose a metapragmatic consideration of such charms that, as Urban (1989) says, deal with "speech about speech in speech about action". In the Argentinean context in which I collected this folktale, the hero is the young son of a rural peasant family, poor and struggling, like the narrator and his audience. The lazy poor boy who marries the princess thanks to the force of the dreams shows how the language is the key both to repair social gaps and to restore collective order.
\end{abstract}

Keywords: charms-wands, belief narratives, performance, Argentina

\section{INTRODUCTION}

In this presentation, I will analyse the formulaic use of a magic charm in an Argentinean folktale, dealing with an invocation to a "wand of virtue", the proper use of which shows the performative force of language. Thanks to this charm, everyday struggle is solved in a world of dream, in which the most important effort is to learn how to use the correct words. Social beliefs in the supernatural are expressed in this tale, in which the wand is a God's gift which allows the hero to avoid struggling. The main gift is actually the 
knowledge of language which permits the hero to make an accurate usage of formulaic discourse, structured in the charm in an epigrammatic way. From a meta-pragmatic perspective, and in the words of Greg Urban, such a charm deals with "speech about speech in speech about action" (URBAN 1984).

In the Argentinean context in which I collected this folktale, the hero is, like the narrator, the young son of rural peasants, poor and struggling. Paradisiac motifs do appear in this tale, reframed in the narrative plot, which expresses the force of believing in the supernatural, not only to solve the problems of everyday life, but also to reach the most incredible dreams, metaphorised in the form of a princess. The poor, lazy boy who marries the princess shows how language is the key to both repair social gaps and restore collective order, even in a difficult context.

\section{CHARMS AND CHARMINGS: SOME THEORETICAL CONSIDERATIONS}

"Virtue wands" are used in Argentinean folk narrative as efficient devices to make dreams come true. ${ }^{1}$

By pronouncing a charm and waving his wand, the Argentinean folk hero John the Lazy manages both to marry the princess and to live without working. In this way, charms are a clear example of "how to do things with words" (AUSTIN 1982), since they reveal the performative power of verbal discourse (KAPALÓ - PóCS - RYAN 2012). In fact, The Oxford Handbook of the History of English includes charms under the entry of "performative practices" enacted "on demand". The syntactic and lexical construction of a charm is based on a sequential repetition of words and structures fixed in a formulaic configuration, and such sequential repetition of words and actions, with a performative effect, is also a distinctive feature of ritual discourse (RAPPAPORT 1992).

Indeed, the power of words in incantations consists of a larger ensemble of ritual procedures, such as gestures. In the tale I am dealing with, the gesture of waving the right hand, made by the narrator to imitate the movement of waving the wand, is essential to the performative efficacy of the charm, along with the intonation of a repetitive formula. In this way, words act as linguistic tools, consisting both of syntactic and semantic strategies, displayed with rhetorical procedures as repetitions and enumeration, with the mediation of supernatural forces, such as heavenly beings (Pócs 1999). All these strategies are used by the narrator in the tale "John the Lazy", in which heavenly forces

\footnotetext{
1 Although in this presentation I focus attention only on one oral version of this tale type, most of the considerations are based on the analysis of a corpus which comprises more than 150 versions collected in the course of fieldwork in La Rioja, Argentina, from 1985 to 2010, published in PALLEIRO $1990 ; 1992 ; 1998 ; 2011$; and 2016. In the versions of this corpus classified as marvelous tales, the presence of a "wand of virtue" is rather frequent.
} 
are represented by the personification of God in the form of a fish, ${ }^{2}$ invocated by the hero each time he pronounces the charm.

The formulaic nature of charms is not merely a stylistic matter since, as aforesaid, charms also have a performative effect, as can be seen in the folktale I deal with, in which the formulaic expression "Wand of virtue that God gave me" acts as a leit-motif with the power of causing certain actions in the narrative plot. Such formulaic structure includes the invocation of a magic object, the wand, personified as a receiver, in a second person who acts as the addressee of the message. This is the distinctive feature of the magic function of language, as described by Roman Jakobson (JAKOBSON 1964).

Among the elements of charming and incantation, Edina Bozóky lists:

1) the naming of the object of the charm (the wand, in this tale),2) the conjuration (here, the command introduced by the causative form "let"); 3 ) the nomination of the helping powers (God himself), 4) actualization of the object by comparing it to other precedents (in this case, the wand "of virtue, that God gave me", which implies a comparison with other kinds of wands), and 5) dramatization in terms of religious or Biblical discourse, such as the acting out of the scene performed by the hero and by the fish personified (BozóKY 2003).

Like Éva Pócs, Bozóky also calls attention to the vocal effects of incantations rhythmical forms, rhymes, alliteration, repetition, anaphora, "stream of words". ${ }^{3}$ Almost all of these elements can be identified both in the charm I am dealing with and in the narrative discourse that serves as the co-text of the charming formula, which acts as an enchantment whose performative force lies in repetition connected with a triple reference to three wishes. As a matter of fact, the hero John the Lazy repeats the magic enchantment three times, and such triple repetition causes and ensures his marriage with the princess.

The development of action is thus generated by this charm. Every time that an obstacle rises up, the force of the formulaic words manages to solve every conflict. In such a way, the charm has not only a stylistic, but also a structural function in the narrative plot. The axis of the folktale is the power of magic objects to transform the hard, daily reality which compels poor peasants to go out to the forest to fetch some wood in an opportunity for a magical encounter with a princess. Such power, concentrated in the "wand of virtue", needs a charm to be activated.

2 It is worth mentioning that zoomorphic representations of supernatural forces are part of collective beliefs in Argentinean rural communities visited during my fieldwork. A clear example of zoomorphic representations of supernatural forces is the "Salamanca" rite, the climatic point of which is the deal with the Devil, where evil forces are represented in the shape of different animals, such as a pig, a dog or a goat. In such a rite, human beings are expected to interact with evil forces before meeting the "great Devil", described as a zoomorphic combination of different animals. The sequential steps of this vernacular rite have been narrated by the local artist Marino Cordoba, who recreated them in a series of ceramic statues as a visual representation in pottery, then explained in verbal discourse (Cordoba in PALleIRo 2016). Nowadays, such iconic representation in pottery statuettes are exhibited in the Folkloric Museum of La Rioja, Argentina and one of them in the Devil Museum of Kaunas, Lituania.

3 Both PóCs (1985-1986) and BozóKY (2003) illustrate the mechanisms that lend a special power to the words in incantations - such as "abracadabra" - which are also connected with the aforementioned magic function of language (JAKOBSON 1964). 


\section{CHARMS AND VERNACULAR BELIEFS}

In this tale, the hero obtains the wand thanks to the fish, which is a metaphorical representation of Christ, whose iconic animal image is the one of a fish. Thus, such a gift can be considered as a sort of heavenly reward for having helped an undefended little fish to return to the water. However, since the hero asks God to repay him for the help, the "do ut des" is the principle that guides all performative actions of the magic "wand of virtue". Magic as taught in the canonic regulations of the Roman Catholic Church to which the narrator belongs has nothing to do with institutional religion. In everyday life and vernacular beliefs, however, such distinctions are not so clear, as the tale itself shows.

There is also an intertextual gap between charms in their contextual performance and the registered form of the narrative text. Bridging this gap between orality and literacy is an unavoidable task when dealing with any oral text, but especially in this one, in which the charm, associated with the wand of virtue, is rooted in contextual beliefs regarding a reward given by the Christian God for having accomplished good actions. Such religious beliefs overlap with other local ones involving performative practices, such as charms.

\section{THE TALE TYPE AND THE NARRATOR'S VERSION}

The version I am dealing with, collected throughout fieldwork in Banda Florida, La Rioja, Argentina, on July $21^{\text {st }}, 1985^{4}$ from the young narrator Fernando Páez, shares some thematic elements with ATU Tale Type 675, "The lazy boy", filed under the matrix "John the Lazy". ${ }^{5}$ At the time I collected this version, its narrator was aged twelve, almost an adolescent, who had heard this version orally from his parents and grandparents. As a reminder, the thematic description of ATU 675 is the following:

"A lazy stupid boy releases a fish (frog, serpent, supernatural being) which gives him the power to make all wishes come true. The lazy boy then makes an axe cut trees by itself, water carry itself, a wagon move itself, an oven carrying him, etc. When the princess laughs at him, he wishes her pregnant (from eating an apple, etc.) She does not know the father of the beautiful child. The king orders a test of paternity, and the child picks the lazy boy out as father (by handing him an apple, ball, golden ball).

(...) The young man wishes to be beautified and makes a castle appear next to the king's" (UTHER 2004:1:371)

${ }_{4}$ Later on, in 1988, I collected another version of this folktale from the same narrator, but I chose this first one to analyse here since the narrative function of the charm is more relevant. In the second register, the narrator provided a summarized version, probably assuming that the receivers had already heard the previous one, narrated three years before.

5 Palleiro 1990; and 2016. As I will explain later on, this criterion of classifying the versions under narrative matrices instead of tale types allows us to assemble fictional tales, along with legends, local cases and other belief narratives in the same matrix (see PALLeIRo 2004). At present, I am working on the project of elaborating an Argentinean Index of Tale Types, also filed into narrative matrices in order to show the incidence of belief narratives in transforming thematic, structural and stylistic folk narrative patterns (PALLEIRO 2020, forthcoming). 
The Argentinean version contains some thematic features of this tale type, the thematic description of which emphasizes the power of wishing. The text of the folktale, as narrated by Fernando Páez, is the following:

"This is the story of John the Lazy. ${ }^{6}$

Once upon a time there was a lazy boy, who didn't want to work. So lazy he was that all the people in the village called him "John the Lazy".

Pedro Ordimán... ${ }^{7}$ that is to say, John the lazy lived all alone with his mother, far away from town, in the countryside.

One winter day, it was very cold, and the mother had no more fire sticks to light the fire. So she called John, and asked him:

- John, could you please go to the forest to bring me some wood, some fire sticks?

- Oh, no, because I'm so lazy! - he replied.

After a while, the mother asked him again to go to the forest to gather some wood, some fire sticks, and John refused once again, because he was altogether too lazy.

At last, the mother began crying with cold, so this time John decided to go out to the forest to gather some fire sticks, some wood. ${ }^{8}$

That we get wooden sticks from the forest, to light the fire in winter. [The narrator makes the gesture of pointing with his right index finger to a set of trees, which can be seen from the place where he is performing his narrative discourse.]

${ }^{6}$ Both in the transcription in Spanish and in the translation into English I have tried to maintain the distinctive features of oral style, such as anaphoric repetitions, rhythmical prose, corrections and even gestures, registered in notes added in the narrative text. It is worth underlining, in this sense, the anaphoric use of "That" at the beginning of the sentence, as a dialectal use of colloquial Spanish of Northwestern Argentina, as well as the polysyndetic use of "And" and "So".

7 "Pedro Ordimán" is a dialectal Spanish phonic transformation of "Pedro Urdemales" (whose literal translation is 'Peter who invents tricks'). Pedro is a well-known trickster of Hispanic and Latin American folklore. It is worth pointing out that in my corpus of Argentinean folk narrative (PALLEIRO 1990; 1992; 1998; 2011; 2016) I collected different versions in which Pedro Ordimán is presented as a healer with supernatural powers. The main tools that he uses to heal are verbal charms and other formulae. In fact, in many tales, Pedro acts as a healer with the supernatural aid of Jesus and the saints. For instance, in the tale entitled "Pedro Ordimán y los dos riñones" ("Peter Ordimán and the two kidneys'), different versions of which I analysed in Palleiro (2001; 2016), Pedro is presented a healer whose success in curing a princess deals with the right use of language. Jesus and the saints warn him against using "bad words" as a sine qua non condition to obtain the desired result of healing the princess. This version could also be considered a metanarrative discourse, the focus of which is the proper use of language. The narrative series "Pedro Ordimán and the miraculous healings" is well-known in the peasant community of Banda Florida, where I registered "John the Lazy", and this is probably the reason why the narrator associates John the Lazy with Pedro Ordimán.

8 It is worth noticing the repetition of similar clauses, such as "some wood, some fire sticks" or "into the little mud, into the stream". This is a distinctive feature of indigenous oral discourse, frequently used in poetic speech of Latin American aboriginal cultures such as the nahuátl and the quechua. This resource, called "diphrase" or "biphrase" ('difrasismo', in Spanish), is connected with a worldview in which each aspect of the life is ruled by the convergence of two complementary principles, like the sun and the moon, the man and the woman (Garibay 1940; León Portilla 2006). 
So John went out, and while he was walking into the forest, he found an almost dry stream, a little mud, ${ }^{9}$ which happened to be on his way.

He was about to jump to reach the other shore, when he heard a soft voice.

- John! - the voice said. - Please, give me some water! I'm dying of thirst!

John looked everywhere to find out where the voice was coming from, but he couldn't see anyone. So distracted he was looking everywhere that he slipped into the little mud.

And there, in the little mud, he found a little fish speaking to him.

- John! Please, give me some water!

- Oh, no! I won't give you any water, because I' m so lazy.

- Come on! Throw me back into the water! Why don't you give me some water? Haven't you seen that I belong to the water? - the fish said.

- Oh, no, I won't give you any water, because I'm so lazy! - John repeated.

The fish went on asking and asking. And so much he insisted that finally John gave him some water, and he threw him into the little mud, into the stream.

When the fish was already safe in the water, John told him:

- Since I have saved you, now you must pay me!

The little fish was God, so he decided to reward John the Lazy because he had helped him. As a reward, he gave John a magic wand of virtue with the power to grant him any wish.

So John went on his way. And he began walking across the forest, until he felt tired.

And when he was very, very tired, he said aloud:

- I am too lazy to go and gather all the fire sticks, all the wood!

And then he remembered the wand of virtue, and he said in a loud voice, almost shouting: Little wand of virtue, that God gave me, let a cart and many truckloads of wood appear right now! And let the wood take me back to my mother's house! [The narrator makes the gesture of waving the wand with his right hand.]

So a cart suddenly appeared, with a large pile of fire sticks on the top.

So John got into the cart, and the self-moving cart rode him on his way home, across the forest, until he arrived to the village.

Before returning to his mother's house, he decided to go for a walk round the village. But then he made up his mind, and he decided to visit the village riding the magic cart.

And in that village, there was a castle. That was the king's castle.

And when John passed by the castle, just there, in the balcony, he saw the princess looking by the window.

When the princess saw John the Lazy standing on the wood, she started laughing.

She was laughing, the princess. She was laughing at John the Lazy, since she had seen him sitting on top of the wood.

As the story tells, this sight of the princess laughing made John very angry. So angry he was that he said aloud:

- Little wand of virtue, that God gave me, let the king's daughter become pregnant right now!

[The narrator makes the gesture of waving his right hand.]

Then he turned back, and he went on his way home, sitting on the top of the wood, inside the self-moving cart.

9 The expression "little mud" to allude to a muddy pool is a queer form, even in Spanish, used by the narrator as a metonymic strategy. Such cumulative use of queer expressions, as well as the use of diminutive forms, constitutes the hallmark of his poetic style. 
So he arrived to the house. And there, in the house, he found his mother, and he gave her all the wood. And in this way, the mother lit the fire, so she was not cold any more.

In the meantime, the king's daughter became ill. And his father called many doctors, but no one could find out what was going wrong with her, until a healer from another town arrived to the palace.

And the healer saw the princess, and then he went to speak to the king, and he said:

- Your daughter is not ill but pregnant. And she will only get well when the child will be born. And he will be holding a golden apple...no! a golden orange in his hand. And the one to whom the boy will give him the orange, he will be his father, and he will marry your daughter!

And, as the story tells, when the pregnancy came to the end, the little child was born, with a golden orange on his right hand.

Then the king called all the young men of the kingdom, and he invited them to the palace to see the child. And all of them went to see the child, but none of them got the orange from the child's hands.

At last, when there was no one left, the king remembered John the Lazy, and he said:

- The only one who didn't come here is that rascal, John the Lazy.

So the king's men went to look for John the Lazy, whose house was far, far away from the palace. And when they arrived there, they told him:

- John, you must go to the palace, to see the new born child!

But John answered:

- How can I go to palace, if I am so poor, and I have no proper clothes to wear?

But suddenly he remembered the little fish, and he asked:

- Little wand of virtue, that God gave me, let the best suit appear here, right now! [The narrator makes the gesture of waving the wand with his right hand.]

And at that very moment, an elegant suit appeared on his chair.

So he put on his new suit, and dressed in such a way, he went to palace to meet the king and the new born child.

And, as soon as he arrived to palace, the new born child saw him, and he stretched his arms, handing him the golden orange.

And then the king said:

- Since you are the little child's father, you must marry my daughter right now!

So he sent his men to warn his daughter. And in the meantime, he took John the Lazy to church. After a while, the bride arrived, and the marriage took place.

And when the ceremony came to the end, John the Lazy commanded:

- Little wand of virtue, that God gave me, let a house and a car appear right now, with a box full of jewels in it; everything, made of gold and silver!

And just there, in front of the church, a car suddenly appeared.

So John got into the car with his wife and the new born child, and he drove them all straight home.

And they all went to the new palace and there, at the entrance, he found a box full of jewels, all made of gold and silver.

And all the people were very surprised, since John the Lazy was so poor.

Then, the king asked him: - John, let us come in to see your house, where you will live with my daughter!

And they all entered the new house, since John the Lazy invited all of them, so everyone could see the new house. 
And John the Lazy went ahead, and behind him, the princess with the little boy in her arms and then, the king and the queen.

And backwards, behind all of them, all the folks, all the neighbours and the village people as well, they all went to see the new house of John the Lazy.

And there, John's mother was waiting at the door for the people to arrive.

And when they went into the house, they all saw how luxurious it was, with all the doors and windows made out of gold and silver.

And so, John invited them all to go inside the palace.

And when they all went inside, the king was very happy to see how beautiful the palace was. So he decided to live there, with the queen, in the other side of the nice palace.

And then, a big celebration took place there, since all was already prepared for the party to begin.

And all of them have been celebrating during the whole day, singing and dancing, eating empanadas and drinking good red wine. ${ }^{10}$

And so they lived happily ever after.

And so the story finishes." (PALleiro 1990:21-26)

\section{THE CHARM AS THE AXIS OF THE SEQUENTIAL STRUCTURE}

Along with the common thematic features of the aforementioned tale type ATU 675, this version also presents structural and stylistic ones corresponding to the matrix "The lazy boy". I deem the matrix as a set of thematic, structural and stylistic features common to different versions of a folktale, identified by intertextual comparison (PALLEIRo 2004). This concept, rooted in Mikhail Bakhtin's characterization of discursive genres (BAJTIN 1982), adds structural and stylistic features to the thematic regularities of the tale types.

The matrix I am dealing with has its thematic focus in the supernatural help that the hero, John the Lazy, receives from a grateful fish in reward for having saved him from dying in the dry earth. According to the laws of three and of the repetition, which are part of the epic laws of folk narrative identified by Axel Olrik when studying the structure of folktales, the structure of this tale is based on three parallel sequences, in which a lazy boy manages to accomplish different tasks with the help of a magical wand (OLRIK 1992). On the other hand, the main rhetoric strategy is the repetition of a charm introduced by the formulaic form: "Little wand of virtue that God gave me, let..." which the protagonist pronounces while waving his wand. As already mentioned, the given charm is the axis of this folktale since both the supernatural help and the sequential action depend on the verbal action of pronouncing this formulaic structure correctly. From this standpoint, the narrative can be considered as a meta-pragmatic discourse dealing with the power of words.

The initial sequence is the request of the mother, who asks John the Lazy to bring her "a few wooden sticks" to light the fire in the cold season. The rascal at first refuses this request because of his laziness, which makes him avoid any effort to accomplish any kind of work. Following the pattern of the aforementioned law of three, formulated by Olrik

${ }_{10}$ Empanada (plural empanadas) is a typical Argentinean food, which can be described as a sort of meat pie. Etymologically, it means "food put into a roll of bread". 
as a structural principle of the folktale, according to which folk narrative has a preference for the number three not only for characters and objects, but also for successive episodes, the mother repeats this request for three times, until, at last, the youngster agrees to go to the forest to look for the wooden sticks. Such triple formulaic repetition aids cohesion and also serves as a mnemonic resource, which helps both the narrator and the audience to remember the narrative plot when the tale is being performed orally.

The second sequence is the encounter with the little fish, in which, on his way across the forest, the hero happens to meet this personified animal imprisoned "in a little mud", after which the fish begins speaking. As mentioned, the fish asks the young guy to give him some water to drink and to help him to return to the water. Once again, according to the triple structure, John denies such request three times since he is too lazy, but at last he accepts. He then gives the fish some water and throws him back in a stream. This sequence presents an evident parallelism with the previous one, in which the two first parts consist of a denial, the third one being an acceptation to satisfy the request both of the mother and of the fish. Such parallelism is a stereotyped strategy of folk discourse, connected with the law of repetition, which provides the narrator a structural pattern to organize episodic development.

The climatic sequence is the one of the three wishes and the magic wand, in which, as a reward for having saved him from dying outside the water, the personified little fish, representing God, gives John the Lazy a wand of virtue with the power to grant him any wish when pronouncing a charm. In this way, the charm becomes the axis of the narrative action. Consequently, the allusion to this magic object makes room for "the three wishes", which are the structural axis of the sequence. John's first wish is to obtain fire sticks for his mother. Thanks to the charm, the wand begins working and the fire sticks with the power of self-transportation to his mother's house suddenly appear. The second micro unit deals with the encounter with the king's daughter: the princess sees John the Lazy standing on the fire sticks inside the cart, and she starts laughing. This action provokes anger from John, who asks the magic wand, as a second wish, to make the king's daughter become pregnant. Every time this charm is pronounced, the verbal request is underlined by the gestures of the narrator, imitating those of the hero, and such gestures are relevant to the correct performance of the charm.

Later on, the third wish is accomplished in the micro sequence in which the selfpropelled cart takes John the Lazy back to his mother's house, where he gives her the wood as requested. This ending shows the power to do things with words by means of a charm, thanks to which the lazy boy accomplishes his task of obtaining the fire sticks without the effort of everyday struggle, as if he were in Paradise. These paradise motifs, such as obtaining benefits without any effort, are similar to the adynata or impossibilia topics. A clear example of this is the self-moving chart, whose action of transporting objects and persons without being guided is impossible in the real world (VAN HoUWELINGEN 2010). Transported back home in such a way, the hero avoids working and prevents the danger of getting ill for the lack of a warm fire by means of the charm, which turns out to be a performative practice enacted on demand, as underlined by the aforementioned The Oxford Handbook of the History of English.

In the following sequence, the climax of which is the child's birth, the king's daughter becomes ill and only one out of many doctors discovers that she is pregnant. Actually, he is not a doctor but a healer, who announces to the king that a child will be born nine 
months later, with an orange in his hand. He adds that the one to whom the child will give the orange, that one will be his father. It is worth noting that in this Argentinean peasant community healers are almost more reliable than doctors in discovering the origin of certain diseases, such as the "evil eye", which consists of staring "hard" at a person with the aim of wishing him or her some danger. Healers have the power to cure such diseases by pronouncing certain charms, which have an important role in Argentinean rural communities, such as Banda Florida. Thus, as can be seen, the charm reflects some aspects of the cultural background of this context. ${ }^{11}$

The sequence of the birth makes room for the recognition of the child's father, in which the king summons all the young men of the kingdom so they can visit the new born child. All the young men obey the order and go to meet the princess, with the exception of John the Lazy, who does not want to go to the palace because he is poor and has inadequate clothes. As previously mentioned, however, he solves this problem by asking the wand of virtue to provide a suit and proper clothes. In this sequence, the narrator inserts another series of three wishes, completed in the next episodes with the requests for a car, jewels and a palace.

While the first series has been connected with the domestic atmosphere of everyday life, this second one is connected with a royal atmosphere. When the charm is pronounced, the suit and the clothes magically appear. Thus, John the Lazy goes to palace and, as soon as he approaches the new born child, he hands John the orange, with the gesture of opening his arms reproduced by the narrator. In this way, John the Lazy marries the king's daughter and, once again, gestures and words, codified in a charm, contribute to making a dream come true.

Since he has married the princess, John asks the wand of virtue to produce a car, as well as a great palace and jewels "all made of gold and silver". Thanks to the power of words, the palace suddenly appears with the jewels inside. Attracted by the luxury of this new palace, not only the princess but also the king and the queen go to live there, in the residence of John the Lazy and his wife. Thus, a supernatural aid, materialized in the delivery of a magic object activated by the charm, allows the hero to accomplish all his desires and to marry the daughter of the king. In such a way, the story provides the restoration of the final order, broken by the poverty and the initial laziness of the hero. This restoration is achieved with the marriage and the change of residence, which protects him and his family against suffering hunger and cold, as a result of the performative efficiency of the charm. Like this, the sequential development clearly shows how the development of the narrative action is due to the force of the charm.

11 Another charm I registered in the same context from some elder friends and neighbours of this young narrator is one which has to be pronounced three times on three consecutive nights while looking steadily at the moon: "Little moon, little moon, give me your good [ luck] and take all bad [luck] away from me". Preferably, this charm must be enunciated on nights of clear moonlight, to propitiate good luck. I also heard this charm in another zone of the Argentinean province of La Rioja, named Aimogasta, in 1985, 1988 and 1999. In fact, these kinds of charms, used to attract good luck, are very common in Northwest Argentinean rural communities. 


\section{RHETORIC CONSTRUCTION AND FORMULAIC STYLE}

As previously mentioned, both the narrative structure and the rhetoric construction of this narrative are based on the repetition of three parallel situations, the origin of which is the set of requests made by the hero to the "wand of virtue" - which serves the function of a magic object. Since this magic object has been given to the hero by a divinity, it has religious value as well. Besides, there is a metaphorical identification of the fish with the Christian divinity, also related to local beliefs. Regarding this metaphorical identification, it is worth remembering the connection between "Jesus" - considered by Christian religion as the son of God - and the Greek term "ichthys", which means 'fish'. Thus, there is a symbolic condensation of the attributes of the fish with those of a supernatural power, linked with the social beliefs of this peasant community.

The distinctive feature of this tale, therefore, is its repetitive style, with an accumulation of sequential units adjusted to the aforesaid "law of triple repetition of parallel situations" (OLRIK 1992). Such units are linked together by an additive mechanism, expressed through the anaphoric use of connectors such as "And", "Then" and "So", in an initial position, with a poly-syndetic effect of emphasis. Another stylistic hallmark of this young narrator is the cumulative use of diminutives with an affective value ("little fish", "little child", "little wand").

Fernando Páez also appeals to the formulaic use of invocations, whose performative value is linked, as already mentioned, with the magic function of language (JAKOBSON 1964), according to which the magic object acts as a receiver of the invocation. Such performative use is the clue to the interpretation of this folktale, based on the repetition of the charm "Little wand of virtue that God gave me, let [the object of desire] appear". Such formulaic oral style confirms how the request contained in the charm can be intensified by means of linguistic tools, which comprise both syntactic and semantic strategies, displayed with rhetorical procedures like repetitions and enumeration (Pócs 1999; 1985-1986; cit. by KLANICZAY 2012). These formulae serve the function of mnemonic strategies as well, to help the narrator remember the sequential order of narrative discourse.

The deployment of dialogue gives a polyphonic, theatrical nuance to the narrative speech. Yet another distinctive feature of the narrator's style is its colourful lexicon, with abundant use of local terms, such as the collective noun "truckload", with a hyperbolic value. Even the specification "Wand of virtue" is a local use, referring to vernacular social beliefs, which tend to associate specific magic objects such as the wand with abstract values like "virtues", connected with the semantic field of Catholic religion. All these discursive strategies emphasize the mediation of supernatural forces, such as God, invoked in the charm.

The adequate use of these resources reveals the performative ability of the narrator, who achieves an effective reception, manifested in smiles and gestures of attention from the audience, as recorded in field notes.

\section{TEXT, CONTEXT AND TEXTUALIZATION}

When considering problems in the translation and textualisation of charms, Maria Eliferova (ELIFEROVA 2011) warns against the difficulty of a literal translation in written 
discourse, contradicting the academic tradition which tends to affirm that the more literal a translation is, the better it is. In his oral discourse, the young narrator Páez uses untranslatable phonic resources, such as vowel elongations, along with proxemic and kinetic resources, such as gestures. He also stresses the intonation of discourse by pronouncing the charm in an acute register with a rhythmic modulation.

The same oral style characterizes the entire narrative discourse, its distinctive features being the cumulative reiterations of phrases like "Oh (...) because I am so lazy!", along with repetition of the charm, whose alliterative effect cannot be translated into English: "Varillita de virtud, que Dios me dio" ('Wand of virtue, that God gave me'). In this way, the verbal speech is emphasized by both verbal and non-verbal actions oriented to commanding the "wand of virtue" so that the hero can make his dream come true with the performative force of the charm.

The analogical association between text and context is another stylistic hallmark of this folktale, textualization of which requires explanatory notes to register the deictic gestures of the narrator. This is how, in his reference to the "fire sticks", Páez establishes a connection between the fictional narrative world and the real one of his daily environment, in a clause that serves as an explanation, reinforced by the deictic gesture of pointing out to some elements of the referential context ("That also here we get wooden sticks from the forest, to light the fire in winter [The narrator makes the gesture of pointing out to a set of trees, which can be seen from the place where he is performing his narrative ]"). In fact, the environment where I collected this folktale is a peasant community in which people do collect wooden sticks to light the fire, as the narrator emphasizes in the aforementioned explanatory clause, which interrupts the narrative sequence. This clause serves the function of shifter, which connects the text with the social context.

The narrator employs updating strategies as well, like the allusion to contemporary elements such as "the car", in an overlap with the royal atmosphere of medieval palaces. Such overlapping is connected with the principle of the addition of heterogeneous semantic units, considered by Jan Mukarovsky as a distinctive feature of the folk message (MUKAROVSKY 1977). In this way, the narrative matrix shows an intertwining between the utopic world of dream - articulated with paradisiac motifs as the one of a provident divinity who helps the hero to live without any effort ${ }^{12}$ - and anchorage in a peasant Argentinean context, where his struggling mother lives in a poor house in the country where she risks freezing to death if nobody brings her wood to light the fire. By using the correct words in the correct situation, the hero manages to make his dreams come true, even in this hard context. The charm helps him to accomplish every desire, such as marrying the princess and getting a beautiful car and a luxurious palace, along with basic issues such as wood to light the fire, in an interlacing between daily needs and royal objects. Such interlacing of dissimilar objects relates to the aforementioned principle of adding heterogeneous semantic units in folk art (MUKAROVSKY 1977), which also shows the importance of apparently irrelevant details in the construction of the narrative message.

12 For further considerations regarding paradise motifs, see VAN HouweLINGEN 2010. 


\section{THE METANARRATIVE DIMENSION}

In the opening clause, the narrator presents the tale as a "story", thus classified as a fictional discourse. Such metanarrative classification is reinforced by the use of the formula "Once upon a time" and by the repetitive form "as the story tells". These fictionalization devices legitimate his individual discourse with the polyphonic framework of previous stereotyped speech acts.

Another metanarrative clause is the one in which the narrator makes the corrections of "orange" instead of "apple", referring to the magic sign of recognition ("...holding a golden apple...No... a golden orange..."), and the one referring to the name of the hero, presented at first as the famous Hispanic trickster "Pedro Ordimán" and then replaced by "John the Lazy" ("Peter Ordimán ...that is to say... John the Lazy ..."). In this last correction, both names refer to typical distinctive features of a folk hero (John the Lazy, Peter who invents tricks). These corrections act as indexical signs of a stereotyped folk narrative code, which includes standardized characters like these folk heroes, and magic objects, such as the wand, the golden orange or the golden apple. The narrator uses such stereotyped patterns in a dynamic counterpoint to contextual updating resources. These and other narrative strategies are the stylistic hallmarks of this version, in which poetic elaboration reveals the aesthetic ability of the narrator, in a tension between stereotypes and variations, oriented toward contextualizing the narrative matrix in the local environment.

\section{FINAL CONSIDERATIONS}

In this Argentinean folktale, the charm is the verbal door to a fictional world, in which every daily struggle is transformed into perfection by the magical force of wishing. The ritual use of words transforms the hard reality in a perfect possibility. In fact, the protagonist pronounces the verb "Let", and this causative form leads the sequential action to the fictional world of fairy tales. Historic circumstances are thus transformed into a utopic atmosphere of kings and princesses, still anchored in the local context. In such a way, the narrative speech expresses the cultural identity of a group, recreated by the individual talent of the narrator, who achieves the result of creating the charming atmosphere of a fairy tale..$^{13}$

Pronouncing the charm in the right way and in the right situation is the key to solving every problem in each sequence, which means this tale can be considered as a metanarrative discourse since, as mentioned above, it deals with "speech about speech in speech about action" (UrBAN 1984).

\footnotetext{
13 For further considerations regarding authorship in folk discourse, see BAUMAN 2004.
} 


\section{REFERENCES CITED}

Austin, John

1982 Cómo hacer cosas con palabras [How to Do Things with Words]. Barcelona: Paidós.

BAJTIN, Mijail [Bakhtin, Michael]

1982 Estética de la creación verbal [Aesthetics of Verbal Creation]. México: Siglo Veintiuno. [1 $1^{\text {st }}$ ed. Moscow 1975]

BAUMAN, Richard

2004 A World of Other's Words. Cross-Cultural Perspectives on Intertextuality. Oxford: Blackwell.

Bozóky, Edina

2003 Charmes et prières apotropaïques [Apotropaic Charms and Prayers]. Louvain: Brepols.

ELIFEROVA, Maria

2011 Translation of Russian $17^{\text {th }}$-Century Charms into English: Problems of Approach. In MikhaILova, Tatyana et al. (eds.) Oral Charms in Structural and Comparative Light Proceedings of the Conference of the International Society for Folk Narrative Research's (ISFNR) Committee on Charms, Charmers and Charming, 183-188. Moscow: Russian State University for the Humanities - Marc Bloch Russian-French Center for Historical Anthropology - Russian Academy of Sciences.

GARIBAY, Angel

1940 Llave del náhuatl [Key to Náhuatl]. México: Otumba.

JAKOBSON, Roman

1964 Closing Statement: Linguistics and Poetics. In Style in Language, compiled by Thomas A. Sebeok, 350-377. Cambridge, MA: MIT Press. (1960).

KAPALÓ, James - Pócs, Éva - RYAN, William (eds.)

2012 The Power of Words: Studies on Charms and Charming in Europe. Budapest - New York: Central European University Press.

KLANICZAY, Gábor

2012 The Power of Words in Miracles, Visions, Incantations and Bewitchments. In Kapaló, James - Pócs, Éva - RYan, William (eds.) The Power of Words: Studies on Charms and Charming in Europe, 281-304. Budapest - New York: Central European University Press.

León Portilla, Miguel

2006 La filosofía náhuatl estudiada en sus fuentes con un nuevo apéndice [The Náhuatl Philosophy Studied in Its Sources with a New Appendix]. México: Unam.

MUKAROVSKY, Jan

1977 Detail as the Basic Semantic Unit in Folk Art. In Burbank, John - STEINER, Peter (eds. and transl.) The Word and Verbal Art: Selected Essays, 180-204. New Haven: Yale University Press.

Nevalainen, Terttu - Closs Traugott, Elizabeth (eds.)

2012 The Oxford Handbook of the History of English. Oxford: Oxford University Press. 
OLRIK, Axel

1992 Principles for Oral Narrative Research. Bloomington: Indiana University Press.

PAlleiro, María

1990 El escondite mágico y otros cuentos folklóricos riojanos [The Magic Hiding Place and Other Folktales from La Rioja, Argentina]. Buenos Aires: Ediciones del Dock.

1992 Los tres pelos del diablo: Cuentos maravillosos de la cultura popular argentina [The Three Hairs from the Devil's Beard. Argentinean Märchen]. Buenos Aires: Ediciones del Sol.

1998 La fiesta en el cielo. Cuentos populares de animales [The Heavenly Wedding. Argentinean Folktales]. Buenos Aires: Ediciones del Sol.

2001 Las artes de curar y sus representaciones narrativas en el repertorio de un narrador folklórico [Narrative Representations of the Arts of Healing in the Repertoire of a Folk Narrator]. Mitológicas XVI:65-113.

2004 Fue una historia real. Itinerarios de un archive [It Has Been a Real Case. A Dossier with Different Itineraires]. Buenos Aires: Instituto de Filología y Literaturas Hispánicas "Amado Alonso" de la Facultad de Filosofía y Letras de la Universidad de Buenos Aires.

2011 Los tres deseos: Cuentos maravillosos de la provincia de La Rioja, República Argentina (The Three Wishes. Argentinean Folktales from La Rioja Province). In PAlleiro, María Inés (ed.) Jornada "Archivos de Narrativa Tradicional Argentina” (ANATRA) 51-52. Buenos Aires: Instituto de Filología y Literaturas Hispánicas "Doctor Amado Alonso" de la Universidad de Buenos Aires.

2016 El cuento folklórico riojano: una aproximación a la narrativa oral [Folktales from La Rioja, Argentina. An Introduction to Oral Narrative]. Buenos Aires: La Bicicleta.

2019 Index of Argentinean Folk Narrative: Tale Types and Matrices in Context. Buenos Aires: Instituto de Filología y Literaturas Hispánicas de la Universidad Pócs, Éva de Buenos Aires "Dr. Amado Alonso". (Forthcoming).

1985-1986 Magyar ráolvasások I-II. [Hungarian Incantations I-II]. Budapest: MTA Könyvtára.

1999 Between the Living and the Dead. A Perspective on Witches and Seers in the Early Modern Age. Budapest: Central Europe University Press.

RAPPAPORT, ROy.

1992 Ritual. In Bauman, Richard (ed.) Folklore, Cultural Performance and Popular Entertainments. A Communications-centered Handbook, 249-260. New York: Oxford University Press.

URBAN, Greg

1984 Speech about Speech in Speech about Action. Journal of American Folklore 97(385):310-328. 
UTHER, Hans

2004 The Types of International Folktales: A Classification and Bibliography, Based on the System of Antti Aarne and Stith Thompson. 3 vols. Helsinki: Academia Scientiarum Fennica.

VAN Houwelingen, Rob

2010 Paradise Motifs in the Book of Revelation. Kampen: Theologische Universiteit.

María Ines Palleiro is full professor at National University of Arts/Buenos Aires University, Argentina, senior researcher in Folk Narrative National Scientific and Technical Research Council, Argentina (CONICET) a and Vice President for Latin America of the International Society for Folk Narrative Research. She is author of more than 200 chapters of books, proceedings and articles in indexed publications, such as "El cuento folklórico riojano. Introducción a la narrativa oral" (Folktales from La Rioja, Argentina. An introduction to oral narrative 2016) "Del cuerpo narrado al cuerpo en movimiento. Folklore, narrativa y construcción social de la alteridad" (Narrated and moving bodies. Folklore, dancing and social construction of alterity 2019), as well as of books containing folk narrative collections, such as "Los tres pelos del diablo". Cuentos maravillosos de la cultura popular argentina (The three hairs from the Devil's beard. Argentinean Märchen) 1992; and series editor of six volumes of the collection Narrative, identity and social memory (2004-2008). E-mail: marinespalleiro@gmail.com

Open Access. This is an open-access article distributed under the terms of the Creative Commons Attribution-NonCommercial 4.0 International License (https://creativecommons.org/licenses/by$\mathrm{nc} / 4.0 /$ ), which permits unrestricted use, distribution, and reproduction in any medium for noncommercial purposes, provided the original author and source are credited, a link to the CC License is provided, and changes - if any - are indicated. 